\title{
Influence of Open Innovation Variables on the Competitive Edge of Small and Medium Enterprises
}

\author{
Ismael Cristofer Baierle ${ }^{1}\left(\mathbb{D}\right.$, Guilherme Brittes Benitez ${ }^{2}{ }^{-}$, Elpidio Oscar Benitez Nara ${ }^{3}$, \\ Jones Luis Schaefer ${ }^{1}$ (D) and Miguel Afonso Sellitto ${ }^{4, * \mathbb{D}}$ \\ 1 Department of Production Engineering, Federal University of Santa Maria (UFSM), Santa Maria, \\ Rio Grande do Sul 97105-900, Brazil; ismael.baierle@acad.ufsm.br (I.C.B.); \\ engjlschaefer@yahoo.com.br (J.L.S.) \\ 2 Department of Production Engineering, Federal University of Rio Grande do Sul (UFRGS), Porto Alegre, \\ Rio Grande do Sul 90035-190, Brazil; guilherme.benitez@ufrgs.br \\ 3 Department of Industrial Systems and Processes, University of Santa Cruz do Sul (UNISC), \\ Santa Cruz do Sul, Rio Grande do Sul 96815-900, Brazil; elpidio@unisc.br \\ 4 Department of Production and Systems Engineering, University of Vale do Rio dos Sinos (UNISINOS), \\ São Leopoldo, Rio Grande do Sul 93022-750, Brazil \\ * Correspondence: sellitto@unisinos.br
}

Received: 16 October 2020; Accepted: 1 December 2020; Published: 4 December 2020

\begin{abstract}
The purpose of this study is to identify how open innovation variables influence the competitive capability of manufacturing small and medium enterprises (SMEs) in a regional territory in Southern Brazil. The research method is a survey of 67 SMEs in Southern Brazil that provided data for an ordinary least squares (OLS) regression model encompassing seven innovation variables and five competitiveness constructs. The results indicate that most innovation initiatives have a low impact on creating a competitive edge in the surveyed companies. The most remarkable positive impacts are (i) technology trends influencing the shop floor productivity, (ii) flexibility influencing internal aspects, and (iii) customer satisfaction and innovative ideas and customized supplies influencing the market orientation. The study also reports that innovation processes are not safe from failures. Some ill-defined innovation initiatives may jeopardize the competitive edge.
\end{abstract}

Keywords: open innovation; competitiveness; SMEs; emerging country; regression analysis; innovation management

\section{Introduction}

Challenges introduced by global competition force small and medium enterprises (SMEs) to grow and lead innovation initiatives [1]. SMEs must often rely on technology-based capabilities [2] conveyed and supported by larger companies geographically collocated in regional clusters [3]. According to [4], the newer an enterprise is, the more it will have to globalize the business, which requires timely information flows [5] to scour the market and to find profitable opportunities [6]. Market-share, profitability, product, service, intellectual capital [7], technology [8], and sustainability [9,10], among others, are critical factors that shape the competition capability of SMEs. SMEs have socioeconomic relevance worldwide and must be prepared to survive and respond to the market's challenges, sometimes translated solely into the differentiation and innovation capacities [11].

Innovation is a cutting-edge objective for companies interested in expanding their business [12]. Innovation can involve different types of change, and it depends on the organization's resources, capabilities, strategies, and requirements. It can also be carried out concerning products, services, operations, processes, and people [13]. Therefore, it is important to explore different innovating ways, 
studying the impact that innovation can generate on growth and competitiveness [14]. Thus, during the exploitation of different forms of innovation, the open innovation process appears, and it adapts according to companies' needs being implemented through managers' demands [15]. Innovation is recognized for creating value and sustaining a competitive advantage [13], and for that, organizations must explore their different ways of innovating and follow the impact generated on growth [14]. SMEs' open innovation has received attention mainly for Product Development Processes (PDP), neglecting the fact that SMEs can also seek innovation in processes or, simultaneously, in products and processes [16]. A critical part of the open innovation process involves managing the knowledge required to achieve strategic goals, such as new product development [17], innovative service offerings, and pioneering new revenue and differentiation [18]. Due to risk and uncertainty [19], it is usually impossible to predict the achievements of innovation initiatives [20]. Therefore, it is important to rely on diversity in exploring possibilities [14] and the inherent complexity of innovation processes [21]. A challenge for SMEs is identifying how innovation will help them increase their competitiveness [22]. Through micro and macro-dynamics with a quadruple helix, it is possible to understand and control the complexity of open innovation [23,24]. Still, it is not easy to predict its competitive results [20], which can generate positive impacts, risks, and uncertainty [19].

Competitiveness can be defined as acquiring a favorable, profitable, and sustainable market position, establishing difficulties for new competitors' entry, and efficiently searching for new markets [25]. Due to globalization, the concept of competitiveness has become more comprehensive, involving territorial competition and systems that create conditions for economic and social development [26], which forces companies to be in constant development [27]. In addition to companies' presence in the market, competitiveness determines profitability and the ability to adapt production to demand, reducing vulnerability to competition and resisting erosion by substitute products $[28,29]$. In competitive markets, SMEs are under pressure to grow and innovate, which is why developing their technological and informational capabilities can be a success factor [2].

To increase the productivity and competitiveness of SMEs, innovation has proved to be a necessary path, where some uncertainties as to the challenge of knowing how innovation can help companies remain $[8,30]$. As SMEs are close to the customer, their flexibility and reactivity to the market can cause disadvantages such as lower productivity, higher costs, and lower competitive performance in the long run, compared to large companies [31,32]. SMEs must be flexible in their operations, continually developing them compared to large companies, to maintain their competitiveness [33,34]. SMEs' strategic determinants can be based on cost leadership, which is only implemented after survival or based on differentiation and focus, triggered by innovation strategies [35].

Some focus on a single, isolated innovation achievement [36-44], which partially hides the overall effect of innovation performance [45,46]. For instance, ref. [47] identifying the influence of multiple marketing criteria on the export performance of SMEs, ref. [48] identifying how individual characteristics of policymakers influence SMEs' performance, ref. [49] identifying how networking capability and experiential learning influence SMEs' performance in global markets and [50] examining the impact of products, processes, and innovations on finance and operations in SMEs. Other recent research has sought the consequences of open innovation in competitiveness in different areas, such as healthcare [38], agrifood sector [43], human resources [51], business [44], product development [52], and tourism companies [39]. According to [41], companies' competitive environment requires strategic innovation, regardless of the industry $[45,46]$.

The aforementioned studies handle innovation in a limited scope. Some related studies were identified in the literature, but they carry empiric or qualitative results or are too specific, being difficult to reproduce in other domains. Thus, understanding which innovation variables have connections with SMEs' competitive variables, managers can predict the results before the implementation. Two questions then arise: (i) Can the impacts of innovation activities on competitiveness be predicted before implementation? and (ii) Can the innovation activities be controlled and managed based on quantitative analysis? To answer these questions, we used a systematic literature review approach to find concepts and perspectives 
related to innovation and competitive variables and tested these hypotheses through an ordinary least squares (OLS) regression analysis. The rest of the article is organized in review, material and methods, results, discussion, and conclusion.

\section{SMEs and Innovation in Emerging Countries}

SMEs seek innovation mainly to meet specific customer demands, i.e., they usually innovate to react to a market opportunity [53]. For example, ref. [54] report innovation initiatives related to new or improved products according to market needs, introducing new components or technology. Usually, SMEs perform worse than large companies in competitive criteria such as flexibility, labor productivity, cost, and delivery $[31,32]$. To overcome such liabilities, SMEs should handle differentiation and innovation processes [11], relying on intrinsic skills usually found in SMEs, such as quality and responsivity [33,34]. Alternatively, when SMEs need to face competition based on cost leadership, strategic drivers must be triggered by innovation strategies [35]. In short, to face global competition, SMEs should combine intrinsic strengths, such as quality and responsivity, with strategic drivers triggered by innovation [55]. Finally, the adoption of environmental practices [56] and promotional strategies and new customer relationships $[55,56]$ may help SMEs build a positive corporate image and enlarge market share.

The Organization for Economic Cooperation and Development [57] classifies innovation into product, service, process, management, and marketing innovations and [58-61] state that innovation comprises new products, services, methods, processes, raw materials, markets, marketing, and organizational structures. According to [61], different innovation types influence companies' overall performance, generating risk and uncertainty that may hinder SMEs' decision-making processes $[62,63]$.

Regarding developing markets, during the 1980s and the 1990s, many countries established mostly domestic business relationships, which provided SMEs with stable, predictable business environments [64]. From 2000 on, many emergent countries decided to open their markets and play a role in the international business arena, which forced SMEs to adopt strategies consistent with global markets [65-67]. One of these strategies is networking [68]. According to [64], SMEs depend on larger companies to penetrate foreign markets. For example, large wineries [69] and furniture companies [3] used to hire collocated SMEs' specific expertise when celebrating international sales contracts or technological agreements. Such kinds of relationships enhance the competitiveness of anchor tenants and SMEs in both domestic and global markets [70].

This article focuses more on SMEs located in emergent markets, particularly in Brazil. The authors of [71] argue that SMEs located in low-income economies have different insertion patterns in local and global value chains than those located in high-income markets. SMEs in emergent markets are strongly influenced by politics and tax incentives at the regional and national levels [72-74]. When governments provide little or no support, SMEs hardly invest or lead innovative initiatives [75].

SMEs are challenged by on-going globalization processes in Brazil, focusing mainly on low-cost products and services destined to other emerging countries [76], and usually associated with larger companies. Currently, Brazilian SMEs are widely diversified and actively take part in the global business arena [72], accounting for $99 \%$ of the number of companies, $52 \%$ of jobs, and $50 \%$ of gross domestic product (GDP) [77]. For comparison, in the United States, SMEs represent $99.7 \%$ of the industry [1]. To overcome such fragilities, ref. [78] argue that SMEs should cooperate by sharing specific resources and expertise, besides associating with larger companies to penetrate markets otherwise unattainable.

Synthesizing, SMEs are important to emergent countries, as they can generate incomes and job positions [79], even if subjected to some managerial inefficiencies [71]. The main challenges are cost reduction and quality improvement, even if SMEs usually retain specific skilled resources and particularly relevant expertise, many times related to the owner's ability [80]. A challenge that remains in SMEs' management is how to support decision-making processes that require the evaluation of innovation initiatives. One key issue is related to access to innovation's influence on the company's 
overall performance [81]. In this sense, ref. [82] conclude that the major problem SMEs face in innovation implementation is the lack of control in the generation of benefits, resulting in permanent loss of opportunity.

\section{Materials and Methods}

The methodological path of the entire study comprises:

- Identification of innovation and competitiveness variables based on recent studies;

- Survey with 316 manufacturing SMEs;

- Variable reduction for regression analysis and principal component analysis aggregates competitiveness indicators.

These steps will be explained in the following sections.

\subsection{Variables Identification}

The subject of this research has a multidisciplinary characteristic, and for this reason, before the survey, an investigation was carried out in the Scopus and Web of Science databases [83]. The selection of variables before a survey is very important for more assertive decision making [84]. This investigation was based on studies focused on innovation that show results that influence some competitive variables. The keywords "Innovation" and "Competitiveness" were searched for in title, abstract, and keywords, in papers published in journals limited to the period from 2010 to the present. As a result, 2748 articles were obtained, and 44 articles with more than 100 citations were analyzed to see if they had adherence to this research. Based on these articles, we arrived at the most recurrent innovation and competitiveness variables presented in Tables 1 and 2.

Table 1. Innovation variables.

\begin{tabular}{llc}
\hline \multicolumn{1}{c}{ Variable } & \multicolumn{1}{c}{ Definition and Theoretical Support } & Mnemonic \\
\hline $\begin{array}{l}\text { Identification of } \\
\text { market requirements }\end{array}$ & $\begin{array}{l}\text { How the company uses customers' requirements and } \\
\text { complaints to support product and service development [57] }\end{array}$ & [MARKET_NEEDS] \\
\hline $\begin{array}{l}\text { Updating with new } \\
\text { trends and technologies }\end{array}$ & $\begin{array}{l}\text { How the company manages new trends and } \\
\text { technologies [17] }\end{array}$ & [TRENDS_TECH] \\
\hline $\begin{array}{l}\text { Partnerships } \\
\text { and cooperation }\end{array}$ & $\begin{array}{l}\text { How the company interacts with agencies, other SMEs, } \\
\text { and anchor tenants to implement innovation [85-87] }\end{array}$ & [PART_COOP] \\
\hline Innovative ideas & How the company uses innovative ideas [88-90] & [INNOV_IDEAS] \\
\hline Innovation practices & How the company implements innovative practices [91] & [INNOV_PRACT] \\
\hline $\begin{array}{l}\text { Adaptability } \\
\text { and flexibility }\end{array}$ & $\begin{array}{l}\text { How the company reacts to innovative } \\
\text { implementation [46,92] }\end{array}$ & [ADAPT_FLEX] \\
\hline $\begin{array}{l}\text { Collaboration with } \\
\text { customers and suppliers }\end{array}$ & $\begin{array}{l}\text { How the company collaborates with partners in innovation } \\
\text { initiatives [93] }\end{array}$ & [CUST_SUPPL] \\
\hline
\end{tabular}

Table 2 presents the competitiveness variables selected.

After identifying the variables, the survey questionnaire was prepared, which comprises seven questions on innovation and eighteen on competitive performance.

\subsection{SMEs Survey}

A survey was conducted with 316 manufacturing SMEs located at the Rio Pardo River Valley, in Southern Brazil, between January and March 2020. A questionnaire was sent by e-mail to these 316 SMEs to capture the level of importance that each company gives to each innovation and competitiveness variable, considering a Likert scale from 1 to 5 [98]. The official regional agency of local development provided the companies' list in the region and their electronic addresses. 
The agency supported the survey with a motivation letter. According to [99], the salience, that is, the survey's association with a respondent's specific interest, may increase the return rate. Five out of the 72 responses were excluded due to the Chemostat ${ }^{\circledR}$ software's inconsistencies, whose main objective is to identify outliers in multivariate samples. Therefore, 67 companies comprised the final sample, which represents $21.20 \%$ of the population. In their study, ref. [99] states that, in e-mail surveys, by the time of the study, the average return rate was $24 \%$. It was more than $30 \%$ in 1995 when the World Wide Web became fully available to commercial traffic. Furthermore, ref. [100] report that the average return rate decreased over time. Therefore, it is not possible to neglect a $21.2 \%$ return rate. Table 3 presents the industry sector and the respondents' profile.

Table 2. Competitiveness variables.

\begin{tabular}{|c|c|c|}
\hline Variable & Definition and Theoretical Support & Mnemonic \\
\hline Customer satisfaction & $\begin{array}{l}\text { Number of customers' complaints divided by the } \\
\text { number of orders [1] }\end{array}$ & [CUST_SATISF] \\
\hline Strategic pricing & $\begin{array}{l}\text { Current price divided by the average product price in the } \\
\text { regional market [1] }\end{array}$ & [STRAT_PRIC] \\
\hline Active customers & $\begin{array}{l}\text { Number of active customers divided by the total number } \\
\text { of customers [1] }\end{array}$ & [ACT_CUST] \\
\hline Customers' loyalty & $\begin{array}{l}\text { Number of customers that repeated orders by the total } \\
\text { number of customers [1] }\end{array}$ & [LOY_CUST] \\
\hline Profits' reinvestment & Reinvested profit amount divided by the total profit [1] & [PROF_REINV] \\
\hline Raw material cost & Raw material cost divided by total revenue [94] & [RAW_COST] \\
\hline $\begin{array}{l}\text { Personal protective equipment } \\
\text { (PPE) usage }\end{array}$ & $\begin{array}{l}\text { Number of employees using PPE divided by the number } \\
\text { of job positions that require PPE [95] }\end{array}$ & [PPE_USAGE] \\
\hline $\begin{array}{l}\text { Control of the enterprise's } \\
\text { working capital }\end{array}$ & $\begin{array}{l}\text { Expected working capital divided by the current } \\
\text { working capital [96] }\end{array}$ & [WORK_CAP] \\
\hline Attraction of new customers & $\begin{array}{l}\text { Number of new customers divided by the total number } \\
\text { of customers [1] }\end{array}$ & [ATTRAC_CUST] \\
\hline Quality control & $\begin{array}{l}\text { Number of certified items divided by the total number of } \\
\text { finished items }[96,97]\end{array}$ & [QUAL_CONTR] \\
\hline Warranty control & $\begin{array}{l}\text { Number of returned items in the warranty period } \\
\text { divided by the total number of delivered items [1] }\end{array}$ & [WARR_CONTR] \\
\hline Machine availability & $\begin{array}{l}\text { Number of available hours for production divided by the } \\
\text { total number of hours [1] }\end{array}$ & [MACH_AVAIL] \\
\hline Production capability & Amount produced divided by production capacity [94] & [PROD_CAP] \\
\hline Orders reliability & $\begin{array}{l}\text { Number of orders delivered on time divided by the total } \\
\text { number of orders [1] }\end{array}$ & [ORDER_RELIAB] \\
\hline Customer complaints & $\begin{array}{l}\text { Number of customers who registered at least one } \\
\text { complaint by the total number of active customers [1] }\end{array}$ & [CUST_COMPL] \\
\hline Sales result & $\begin{array}{l}\text { Expected sales result divided by the current sales } \\
\text { results [1] }\end{array}$ & [SALES_RES] \\
\hline Labor productivity & $\begin{array}{l}\text { Number of items produced per capita divided by the } \\
\text { average number of items produced per capita in the local } \\
\text { market [1] }\end{array}$ & [LABOR_PRODUCT] \\
\hline Absenteeism & $\begin{array}{l}\text { Number of absent hours divided by the total number of } \\
\text { worked hours [1] }\end{array}$ & [LABOR_ABSENT] \\
\hline
\end{tabular}

According to [101], having multiple respondents is less important than having the right respondent, who is one who knows the phenomenon under investigation well, has experience in the field, and is capable and is willing to provide the requested information. Furthermore, according to [101], the researchers involved have a responsibility to present evidence that their data was obtained from 
valid key informants. Thus, the survey was carried out only with SMEs from the food and beverage, metal, furniture, textiles, machinery, and equipment sectors because the most representative sectors in the region of the emerging country studied, where $87 \%$ of the respondents were composed by owners or managers, were considered valid key informants. Other correlated studies can validate this survey. In their study, ref. [1] present a competitiveness scale, outlining the variables that influence competitiveness in SMEs in Southern Brazil, using survey data from 72 industrial SME managers. In the study of [96], responses were collected through a survey with 34 slaughterhouse companies of Southern Brazil and 9 specialists in the health and safety area to establish a prioritization ranking of occupational health and safety key performance indicators affecting business competitiveness. In another study [102], a survey was conducted with 67 people from tobacco production, suppliers of inputs, government, unions, and tobacco companies to analyze the sustainability reports from multinational tobacco companies in Southern Brazil. Finally, the survey of this research can be classified as being of type one, where the independent and dependent variables are the perceptions of a single manager [103]. According to [104,105], the acceptability of a type one survey when studying SMEs states that there is usually a single decision-maker in these companies. Based on the manager's answers, it was possible, using principal component analysis (PCA), to complete variables reduction.

Table 3. Industry sector and respondents' profile.

\begin{tabular}{cccc}
\hline Industry & $\%$ & Respondent & $\%$ \\
\hline Food and beverage & $25 \%$ & Owner & $57 \%$ \\
Metal products & $22 \%$ & Manager & $16 \%$ \\
Furniture & $15 \%$ & Director & $7 \%$ \\
Pharmaceutical and chemical & $10 \%$ & Supervisor & $7 \%$ \\
Machinery and equipment & $10 \%$ & Assistant & $7 \%$ \\
Footwear & $7 \%$ & Responsible/in charge & $3 \%$ \\
Textile & $5 \%$ & External consultant & $3 \%$ \\
Plastic & $3 \%$ & & \\
Electronics & $3 \%$ & & \\
Wooden products & $3 \%$ & & \\
\hline
\end{tabular}

\subsection{Variables Reduction for Regression Analysis}

A principal component analysis (PCA) can help identify structures and reduce the number of variables by removing those that do not combine with others [106]. As the set of competitiveness variables was high, we applied PCA and tested multicollinearity using the variance inflation factor (VIF) [107]. SPSS ${ }^{\circledR} 22$ performed all the tests. Such a strategy was used previously in similar studies by $[108,109]$. PCA requires (i) verifying the sample adequacy by the Kaiser-Mayer-Olkin (KMO, that must be greater than 0.600 ), the Barlett's test of sphericity ( $p$-value must be lower than 0.05 ), and the measure of sampling adequacy (MSA), and (ii) rotating the sample to find the best balance among factors [107]. The KMO was 0.642, Barlett's test had a $p$-value $<0.001$, and the MSA test indicated that almost $70 \%$ of the variables had values higher than 0.50 , as required by [107].

The varimax orthogonal rotation [107] with five factors provided the most balanced factor loading for the PCA. We followed an iterative process, taking into account the eigenvalues, which should be higher than 1.0, and the percentage of explained variance, which should be greater than $60 \%$ of the total variance [107]. Table 4 shows the entire set of PCA results (varimax, converged in nine iterations).

Analyzing Table 4, the competitiveness variables [CUST_SATISF], [PROF_REINV], and [LABOR_ABSENT] were excluded as the loading factors are less than 0.5 (weak-loading) or load in more than one factor (difference less than 0.2, cross-loading). A new test without the three variables showed low load factors for [WORK_CAP], [WARR_CONTR], and [ORDER_RELIAB], which were also excluded. Table 5 shows the final result of the PCA. No further exclusion was required as all commonalities remain higher than 0.500 . Table 5 shows the model without the variables excluded. 
Table 4. Rotated factor-loading matrix for competitiveness model.

\begin{tabular}{|c|c|c|c|c|c|c|}
\hline \multirow[b]{2}{*}{$\begin{array}{c}\text { Competitiveness } \\
\text { Variables }\end{array}$} & \multicolumn{5}{|c|}{ Factor Loadings } & \multirow[b]{2}{*}{ Communalities } \\
\hline & $\begin{array}{c}\text { Factor 1: } \\
\text { Product } \\
\text { Performance }\end{array}$ & $\begin{array}{l}\text { Factor 2: } \\
\text { Productivity on } \\
\text { the Shop Floor }\end{array}$ & $\begin{array}{l}\text { Factor 3: } \\
\text { Internal } \\
\text { Aspects }\end{array}$ & $\begin{array}{c}\text { Factor 4: } \\
\text { Customer } \\
\text { Satisfaction }\end{array}$ & $\begin{array}{c}\text { Factor 5: } \\
\text { Market } \\
\text { Orientation }\end{array}$ & \\
\hline [ACT_CUST] & 0.803 & 0.004 & 0.158 & 0.083 & 0.166 & 0.032 \\
\hline [LOY_CUST] & 0.705 & 0.133 & -0.144 & 0.323 & 0.124 & 0.013 \\
\hline [QUAL_CONTR] & 0.692 & 0.090 & 0.161 & -0.067 & -0.143 & 0.275 \\
\hline [MACH_AVAIL] & 0.106 & 0.804 & -0.141 & 0.181 & 0.002 & -0.050 \\
\hline [PROD_CAP] & -0.065 & 0.763 & 0.158 & 0.066 & 0.210 & 0.178 \\
\hline [LABOR_PRODUCT] & 0.385 & 0.644 & 0.244 & -0.050 & 0.089 & 0.009 \\
\hline$\left[\mathrm{RAW} \_\mathrm{W} \_\mathrm{COST}\right]$ & 0.070 & 0.053 & 0.873 & -0.101 & -0.054 & -0.128 \\
\hline [PPE_USAGE] & 0.163 & 0.066 & 0.665 & 0.430 & 0.197 & 0.010 \\
\hline [WORK_CAP] & 0.159 & 0.090 & 0.481 & 0.651 & 0.049 & -0.149 \\
\hline [WARR_CONTR] & -0.012 & 0.151 & -0.014 & 0.741 & -0.005 & 0.101 \\
\hline [CUST_COMPL] & 0.271 & 0.069 & -0.054 & 0.477 & 0.531 & 0.124 \\
\hline [STRAT_PRIC] & 0.009 & 0.075 & 0.097 & -0.003 & 0.809 & 0.102 \\
\hline [SALES_RES] & -0.225 & 0.369 & 0.403 & 0.217 & -0.134 & 0.538 \\
\hline [ATTRAC_CUST] & 0.337 & -0.016 & -0.186 & 0.338 & -0.092 & 0.653 \\
\hline [ORDER_RELIAB] & 0.138 & 0.033 & -0.131 & -0.179 & 0.236 & 0.630 \\
\hline [CUST_SATISF] * & 0.481 & 0.105 & 0.366 & -0.143 & 0.464 & 0.146 \\
\hline [PROF_REINV] * & 0.175 & -0.237 & 0.388 & 0.341 & 0.117 & 0.393 \\
\hline [LABOR_ABSENT] * & 0.033 & 0.479 & -0.117 & 0.111 & 0.555 & -0.192 \\
\hline Eigenvalue & 3.473 & 1.710 & 1.509 & 1.228 & 1.128 & \\
\hline $\begin{array}{c}\% \text { of variance } \\
\text { explained (cumulative) }\end{array}$ & $26.71 \%$ & $39.86 \%$ & $51.47 \%$ & $60.91 \%$ & $69.59 \%$ & \\
\hline
\end{tabular}

Note: * excluded variables.

Table 5. Model without the excluded variables.

\begin{tabular}{|c|c|c|c|c|c|c|}
\hline \multirow[b]{2}{*}{$\begin{array}{l}\text { Competitiveness } \\
\text { Variables }\end{array}$} & \multicolumn{5}{|c|}{ Factor Loadings } & \multirow[b]{2}{*}{ Communalities } \\
\hline & $\begin{array}{c}\text { Factor 1: } \\
\text { Product } \\
\text { Performance }\end{array}$ & $\begin{array}{l}\text { Factor 2: } \\
\text { Productivity on } \\
\text { the Shop Floor }\end{array}$ & $\begin{array}{l}\text { Factor 3: } \\
\text { Internal } \\
\text { Aspects }\end{array}$ & $\begin{array}{c}\text { Factor 4: } \\
\text { Customer } \\
\text { Satisfaction }\end{array}$ & $\begin{array}{c}\text { Factor 5: } \\
\text { Market } \\
\text { Orientation }\end{array}$ & \\
\hline [ACT_CUST] & 0.803 & 0.002 & 0.202 & 0.241 & -0.029 & 0.744 \\
\hline [LOY_CUST] & 0.674 & 0.205 & -0.206 & 0.334 & 0.024 & 0.651 \\
\hline [QUAL_CONTR] & 0.765 & 0.078 & 0.152 & -0.163 & 0.097 & 0.651 \\
\hline [MACH_AVAIL] & 0.098 & 0.865 & -0.146 & 0.039 & -0.027 & 0.781 \\
\hline [PROD_CAP] & -0.063 & 0.803 & 0.130 & 0.205 & 0.138 & 0.727 \\
\hline [LABOR_PRODUCT] & 0.357 & 0.599 & 0.270 & 0.043 & 0.102 & 0.571 \\
\hline [RAW__COST] & 0.071 & 0.053 & 0.892 & -0.114 & -0.076 & 0.823 \\
\hline [PPE_USAGE] & 0.172 & 0.059 & 0.676 & 0.413 & 0.238 & 0.717 \\
\hline [STRAT_PRIC] & -0.001 & 0.168 & 0.116 & 0.704 & -0.200 & 0.577 \\
\hline [CUST_COMPL] & 0.207 & 0.056 & -0.082 & 0.753 & 0.280 & 0.698 \\
\hline [ATTRĀC_CUST] & 0.432 & -0.083 & -0.291 & 0.075 & 0.712 & 0.791 \\
\hline [SALES_RES] & -0.167 & 0.278 & 0.300 & -0.019 & 0.810 & 0.852 \\
\hline Eigenvalue & 3.103 & 1.707 & 1.461 & 1.211 & 1.100 & \\
\hline $\begin{array}{c}\% \text { of variance } \\
\text { explained (cumulative) }\end{array}$ & $25.861 \%$ & $40.082 \%$ & $52.257 \%$ & $62.352 \%$ & $71.518 \%$ & \\
\hline
\end{tabular}

Thurstone's method supported by SPSS 18 software produced the factorial scores for the five constructs: (i) product performance-[ACT_CUST], [LOY_CUST], and [QUAL_CONTR] related to customer and product monitoring and control; (ii) productivity-[MACH_AVAIL], [PROD_CAP], and [LABOR_PRODUCT] related to the production on the shop floor; (iii) internal aspects-[RAW_COST] and [PPE_USAGE] related to aspects which directly affect the employees and their work; (iv) customer satisfaction-[STRAT_PRIC] and [CUST_COMPL] related to indicators that measure the customer satisfaction and strategies to satisfy them; and (v) market orientation-[ATTRAC_CUST] and [SALES_RES] related to metrics that analyze the market state and how to achieve new customers. This last factor meets two issues present in the study of [109] about Brazil's innovation: market orientation and technology acquisition. Two sets arise-competitive constructs ( 1 to 5 ) and innovation variables (6 to 12)-Table 6 shows descriptive statistics analysis and correlations among them. 
Table 6. Correlation matrix and descriptive analysis.

\begin{tabular}{|c|c|c|c|c|c|c|c|c|c|c|c|c|c|c|c|c|c|c|}
\hline & & & Mean & S.D. & Skew-Ness & Kurto-Sis & 1 & 2 & 3 & 4 & 5 & 6 & 7 & 8 & 9 & 10 & 11 & 12 \\
\hline 1 & \multirow{5}{*}{$\begin{array}{l}\text { Competitive } \\
\text { Constructs }\end{array}$} & $\begin{array}{l}\text { Product } \\
\text { performance }\end{array}$ & 3.881 & 0.653 & -0.362 & -0.337 & - & & & & & & & & & & & \\
\hline 2 & & $\begin{array}{l}\text { Productivity on } \\
\text { shop floor }\end{array}$ & 3.915 & 0.634 & -0.169 & -0.366 & $0.268^{*}$ & - & & & & & & & & & & \\
\hline 3 & & Internal aspects & 4.239 & 0.714 & -0.773 & 0.196 & 0.22 & 0.21 & - & & & & & & & & & \\
\hline 4 & & $\begin{array}{l}\text { Customer } \\
\text { satisfaction }\end{array}$ & 3.903 & 0.629 & -0.327 & 0.295 & $0.309 *$ & $0.277^{*}$ & 0.19 & - & & & & & & & & \\
\hline 5 & & Market orientation & 4.321 & 0.601 & -0.992 & 1.173 & 0.22 & 0.20 & 0.11 & 0.14 & - & & & & & & & \\
\hline 6 & \multirow{7}{*}{$\begin{array}{l}\text { Innovation } \\
\text { Variables }\end{array}$} & [MARKET_NEEDS] & 4.254 & 0.636 & -0.268 & -0.615 & 0.281 * & 0.03 & 0.20 & 0.271 * & $0.359 * *$ & - & & & & & & \\
\hline 7 & & [TRENDS_TECH] & 3.657 & 0.946 & 0.084 & -1.019 & 0.20 & $0.431 * *$ & 0.10 & 0.20 & $0.450 * *$ & $0.348^{* *}$ & - & & & & & \\
\hline 8 & & [PART_COOP] & 3.672 & 0.877 & -0.824 & 1.277 & $0.248^{*}$ & $0.267^{*}$ & $0.260 *$ & 0.17 & $0.404^{* *}$ & $0.315^{* *}$ & $0.373^{* *}$ & - & & & & \\
\hline 9 & & [INNOV_IDEAS] & 3.806 & 0.973 & -0.409 & -0.770 & $0.368^{* *}$ & 0.21 & $0.286^{*}$ & 0.18 & $0.536^{* *}$ & 0.399 ** & $0.437^{* *}$ & $0.492 * *$ & - & & & \\
\hline 10 & & [INNOV_PRACT] & 3.821 & 0.952 & -0.280 & -0.895 & $0.404^{* *}$ & 0.23 & $0.242 *$ & $0.287^{*}$ & $0.367^{* *}$ & $0.426^{* *}$ & $0.435^{* *}$ & $0.545^{* *}$ & $0.665^{* *}$ & - & & \\
\hline 11 & & [ADAPT_FLEX] & 3.806 & 0.839 & -0.408 & -0.250 & $0.298^{*}$ & 0.301 * & $0.331^{* *}$ & $0.337^{* *}$ & $0.321^{* *}$ & 0.21 & $0.335^{* *}$ & 0.283 * & 0.399 ** & $0.487^{* *}$ & - & \\
\hline 12 & & [CUST_SUPPL] & 3.612 & 1.044 & -0.472 & -0.316 & 0.12 & $0.247 *$ & 0.02 & 0.06 & $0.431^{* *}$ & 0.22 & $0.262 *$ & 0.17 & 0.24 & 0.19 & $0.293 *$ & - \\
\hline
\end{tabular}

Note: ${ }^{*} p<0.01 * * p<0.05$ 


\section{Results}

We used ordinary least square (OLS) regression in SPSS $20^{\circledR}$ software to understand innovative procedures' influence on competitiveness constructs. OLS regression should be used only if some standard requirements are achieved, such as normality, linearity, and homoscedasticity [107]. The skewness and kurtosis values reported in Table 6 suggest that the variables can be assumed as normally distributed since they are between the threshold of \pm 2.58 , represented in z-distribution as $\alpha=0.01$ [107]. We also analyzed collinearity by plotting the partial regressions for the independent variables, while homoscedasticity was visually examined in plots of standardized residuals against predicted value. The dataset meets these requirements. To verify multicollinearity, we calculate the variance inflation factor $(\mathrm{VIF})$. As all VIF $<3.0$ (below the threshold VIF $=10.0$ ), multicollinearity is not a concern in the regression model [107]. We performed five independent regression models, one for each of the competitiveness constructs. Table 7 shows the results.

Table 7. Results of the regression analysis.

\begin{tabular}{cccccc}
\hline \multirow{2}{*}{$\begin{array}{c}\text { Innovation } \\
\text { Variables }\end{array}$} & $\begin{array}{c}\text { Competitiveness Constructs } \\
\text { (i) Product } \\
\text { Performance }\end{array}$ & $\begin{array}{c}\text { (ii) Productivity on } \\
\text { the Shop Floor }\end{array}$ & $\begin{array}{c}\text { (iii) Internal } \\
\text { Aspects }\end{array}$ & $\begin{array}{c}\text { (iv) Customer } \\
\text { Satisfaction }\end{array}$ & $\begin{array}{c}\text { (v) Market } \\
\text { Orientation }\end{array}$ \\
\hline [TRENDS_TECH] & -0.035 & $0.376^{* * *}$ & -0.109 & 0.040 & 0.181 \\
[ADAPT_FLEX] & 0.128 & 0.151 & $0.307^{* *}$ & $0.283^{* *}$ & 0.049 \\
[INNOV_IDEAS] & 0.148 & -0.040 & 0.173 & -0.097 & $0.360^{* *}$ \\
[CUST_SUPPL] & -0.013 & 0.131 & -0.114 & -0.082 & $0.264^{* *}$ \\
[PART_COOP] & 0.003 & 0.139 & 0.162 & 0.014 & 0.150 \\
[INNOV_PRACT] & 0.207 & 0.005 & -0.091 & 0.118 & -0.149 \\
[MARKET_NEEDS] & 0.121 & -0.192 & 0.117 & 0.200 & 0.101 \\
F-value & $2.139^{*}$ & $3.026^{* *}$ & $1.854^{*}$ & $1.749^{* *}$ & $6.760^{* * *}$ \\
$\mathrm{R}^{2}$ & 0.202 & 0.264 & 0.180 & 0.172 & 0.445 \\
Adjusted R $R^{2}$ & 0.108 & 0.177 & 0.083 & 0.074 & 0.379 \\
\hline
\end{tabular}

Notes: $n=67$ enterprises.; ${ }^{*}<0.1 ;{ }^{* *} p<0.05 ;{ }^{* * *} p<0.01$.

Models (i) and (iii) were significant at $p<0.1$, Models (ii) and (iv) were significant at $p<0.05$, and Model (v) was significant at $p<0.01$. As the regressions explain the relationships between the variables and do not aim to perform a prediction model, low R-squares, and adjusted R-squares are less relevant [110].

The results allow the conclusion that Model (i), Product performance, does not show significant positive or negative effects of the innovative variables. Model (ii), Productivity on the shop floor, presents only one significant, positive effect ( $\beta=0.376, p=0.006)-$ monitoring of new trends and technologies [TRENDS_TECH]. Model (iii), Internal aspects, presents only one significant, positive effect ( $\beta=0.307, p=0.033$ )—production adaptability and flexibility [ADAPT_FLEX]. Model (iv), Customer satisfaction, has only one significant, positive effect $(\beta=0.283, p=0.049)$-production adaptability and flexibility [ADAPT_FLEX]. Finally, Model (v), Market orientation, has two significant, positive effects—estimulate the employees' ideas [INNOV_IDEAS] $(\beta=0.360, p=0.011)$ and manage the supply chain [CUST_SUPPL] $(\beta=0.264, p=0.014)$. Therefore, all the models are significant and present at least one positive effect.

\section{Discussion}

Seven variables related to innovation processes ([MARKET_NEEDS], [TRENDS_TECH], [PART_COOP], [INNOV_IDEAS], [INNOV_PRACT], [ADAPT_FLEX], [CUST_SUPPL]) were analyzed. Several studies retrieved in Table 2 defend multiple approaches to innovation and report positive results of applications. Further studies also present positive results from the innovation process in human resources management [14], in solving recurring customer problems [111], in improving manufacturing process and service [112], in technology policy development [113], and environmental policies and ISO14001 implementation [114]. The authors of [115], based on [116,117], argue that the innovation 
process should be treated by holistic approaches, not a new product or process development. According to [118], it is important to implement innovation processes to measure shop floor performance indicators to ensure a competitive advantage. Moreover, ref. [119] emphasize that measurement allows fostering useful new ideas. Thus, ref. [113] concludes that incorporating different innovation variables increases the companies' competitiveness, which is a positive impact. Table 8 compares the reports of the studies of Table 1 with the findings of this study.

Table 8. Comparison with other studies.

\begin{tabular}{rccccc}
\hline \multirow{2}{*}{ Author } & Innovation Variable & \multicolumn{2}{c}{ Correlated Studies } & \multicolumn{2}{c}{ This Study } \\
\cline { 3 - 6 } & & Positive Impacts & $\begin{array}{c}\text { Negative } \\
\text { Impacts }\end{array}$ & Positive Impacts & $\begin{array}{c}\text { Negative } \\
\text { Impacts }\end{array}$ \\
\hline$[57]$ & {$[$ MARKET_NEEDS] } & Competitive advantage & - & No significant results & - \\
\hline$[17]$ & {$[$ TRENDS_TECH] } & Company performance & - & Productivity & - \\
\hline$[85]$ & {$[$ PART_COOP] } & $\begin{array}{c}\text { Product and } \\
\text { process innovation }\end{array}$ & - & No significant results & - \\
\hline$[88]$ & {$[$ INNOV_IDEAS] } & $\begin{array}{c}\text { Improve } \\
\text { organizational performance }\end{array}$ & - & Market orientation & - \\
\hline$[113]$ & {$[$ INNOV_PRACT] } & Company competitiveness & - & No significant results & - \\
\hline$[112]$ & {$[$ ADDAPT_FLEX] } & Company performance & - & $\begin{array}{c}\text { Internal aspects } \\
\text { Customer satisfaction }\end{array}$ & - \\
\hline$[111]$ & {$[$ CUST/SUPPLIERS] } & Company performance & - & Market orientation & - \\
\hline
\end{tabular}

This study reports that some innovation variables have no significant impact on most competitiveness variables. A possible cause is that, in the sample, immediate requirements rather than business opportunities drive most entrepreneurial efforts, i.e., business decisions are mostly reactive.

Additionally, the literature says [57] that new product developments can provide a competitive edge to companies since new or improved products do not face immediate competition. Our study pointed out that introducing new products may not bring any positive impact even if free from competition. A presumable cause may be that customers may hardly see value in something they do not demand. Therefore, the lack of market demand may be the main obstacle to innovation in general. In their study, the authors of [17] show that marketing actions may be important for companies to help buyers understand and appreciate offers based on technological innovation. The sampled companies simply react to market needs by improving the manufacturing process. For [85], cooperative networks can generate positive impacts, mostly regarding new market opportunities. Due to the observed reactive managerial culture, this is not true in the sampled companies. To [88], the brainstorming practices may generate positive impacts if abstract ideas are considered in the early-stage, not yet fine-tuned, which differs from the practice in the sampled companies that recognize only marketing effects. In their research, the authors of [113] conclude that encouraging constant innovation variables within organizations is a competitive differential, which was not possible to prove in our study. In their study [112], the authors documented that an organization's adaptability and flexibility can positively reflect the company's performance. This study shows that this performance improvement can be both internal and external for consumer satisfaction. Finally, ref. [111] conclude that the organizational culture of innovation support improves inter-departmental coordination by unveiling innovation opportunities. Therefore, the company may perceive positive impacts on shop floor productivity and customer satisfaction.

According to [119], the culture of the dynamics of open innovation is cyclical and follows a quadruple helix, composed of actors from industry, government, society, and university. The results presented in Table 8 show exactly open innovation variables that are directly related to one or more agents of the micro and macro dynamics of the quadruple helix. Table 9 below shows how each innovation variable relates to the quadruple helix. 
Table 9. Relationship of open innovation variables with quadruple helices.

\begin{tabular}{cc}
\hline Open Innovation Variables & Quadruple Helix \\
\hline [MARKET_NEEDS] & Society \\
[TRENDS_TECH] & Industry, Government, and Society \\
[PART_COOP] & Industry and Government \\
[INNOV_IDEAS] & Industry and University \\
[INNOV_PRACT] & Industry and University \\
[ADAPT_FLEX] & Industry and University \\
[CUST/SUPPLIERS] & University \\
\hline
\end{tabular}

Table 9 shows that the open innovation variables studied in this paper have a relationship with the quadruple helix. This shows the great importance of companies to approach the university, to help develop new ideas, new technologies, and adapt to new realities. It also shows that society and government have important roles as new trends, new needs, or new legal requirements and requirements emerge from them. Finally, the industry itself can be more collaborative to accelerate the development of new technologies.

Finally, comparing our results with the literature, it is possible to observe that innovation may or may not generate positive impacts. Therefore, ill-defined innovation processes may cause losses or unexpected undesired results. This can occur because most related studies present empirical results and are not based on qualitative data, which does not allow for statistical analysis. Thus, the results are based on each author's specific knowledge and are not subject to statistical proof. Empirical conclusions can generate unexpected results, and which can lead to unexpected expenses or costs. Our results suggest that any innovation action can be previously studied, and the results can be predicted, avoiding negative impacts.

\section{Conclusions}

This paper's main contribution was that open innovation variables influence SMEs' competitiveness, and there is no viability to implement innovation in the industry without a study or without analyzing the impacts on competitiveness. Our models indicated the innovation activities that have the greatest influence on the constructs of competitiveness. It can also be highlighted that an innovation variable may influence more than one competitiveness construct, which differs from other studies. Theoretically, this paper's results can serve as a basis for other studies since it shows empirical evidence of innovation's impacts on SMEs' competitiveness. This study can be replicated in other sectors of the industry, as well as in other countries.

Therefore, it is necessary to analyze the context in which each SME is inserted since there is no way to implement innovation in the industry without a study or without analyzing the impacts on competitiveness. Our models have indicated that competitiveness variables mostly influenced by the innovation activities are the internal aspects and market orientation, and the less influenced is customer/product monitoring. It can also be highlighted that an innovation variable may influence more than one competitiveness construct, which differs from other studies.

This answers the question (i) raised in the introduction: Can the impacts of innovation activities on competitiveness be predicted before implementation? It is evident that all the innovation processes presented in this paper positively impact some competitiveness construct but, in some cases, bring no relevant impacts. This shows that it is possible to anticipate the effects of implementing some kind of innovation before starting to practice. With this, all impacts can be evaluated in advance so that only positive impacts can be sought and attempts to neutralize or at least prepare for negative impacts in another area. Additionally, the question (ii) Can the innovation activities be controlled and managed based on quantitative analysis? SMEs can use these results in the elaboration of new strategies that aim at increasing their performance since it presents evidence that indicates which variables of innovation could be utilized to achieve some competitiveness index. 
On the other hand, it shows that before implementing some innovation procedure, it is necessary to conduct an evaluation to avoid or minimize negative impacts as well as jeopardizing expected positive results. The results can also help minimize costs since it shows that it is possible to predict the impact of the results and whether it will deliver good results for SMEs. Finally, policymakers should not consider innovation procedures as absolutely safe from shortages. The results state that some procedures could even generate competitive withdrawal.

This study has limitations. It was carried out only with SMEs from the food and beverage, metal, furniture, textiles, machinery, and equipment sectors in an emerging country, but the study can be extended to other sectors and to other countries to compare results. However, this may not be reflective of all SMEs because we indicate how innovation is seen and how it should be addressed, and this can serve as a basis for studies to be conducted in other emerging countries, showing the importance of studying the impacts of any innovation activity before implementing the changes. Studies can also be conducted with large companies to compare whether micro and small businesses can be compared to large firms. This study can help SME managers to improve their decision-making processes concerning innovation and competitiveness. Furthermore, this paper was limited to the perceptions of importance given by SMEs' managers to innovative procedures. Further studies should consider the managers' frequency of each of the innovative procedures to capture each SMEs' real scenario and help them to reach the correct innovation management.

Author Contributions: Conceptualization, I.C.B., M.A.S., J.L.S., E.O.B.N.; methodology, I.C.B., M.A.S., J.L.S., E.O.B.N.; software, I.C.B., M.A.S., G.B.B.; validation, I.C.B., M.A.S., G.B.B.; formal analysis, I.C.B., M.A.S., investigation, I.C.B., M.A.S., J.L.S., E.O.B.N.; resources, I.C.B., M.A.S.; data curation, I.C.B., M.A.S.; writing—original draft preparation, I.C.B., M.A.S., J.L.S., E.O.B.N., G.B.B.; writing-review and editing, I.C.B., M.A.S., J.L.S., E.O.B.N., G.B.B.; visualization, I.C.B., M.A.S.; supervision, I.C.B., M.A.S., E.O.B.N.; project administration, I.C.B., M.A.S.; funding acquisition, I.C.B., M.A.S. All authors have read and agreed to the published version of the manuscript.

Funding: This research was funded by CAPES and CNPq, the Brazilian Research Agencies, under grants No. 88887.464876/2019-00 and 302570/2019-5.

Conflicts of Interest: The authors declare no conflict of interest. The funders had no role in the design of the study; in the collection, analyses, or interpretation of data; in the writing of the manuscript, or in the decision to publish the results.

\section{References}

1. Schaefer, J.L.; Baierle, I.C.; Sellitto, M.A.; Siluk, J.C.M.; Furtado, J.C.; Nara, E.O.B. Competitiveness Scale as a Basis for Brazilian Small and Medium-Sized Enterprises. Eng. Manag. J. 2020. [CrossRef]

2. Raymond, L.; Uwizeyemungu, S.; Fabi, B.; St-Pierre, J. IT capabilities for product innovation in SMEs: A configurational approach. Inf. Technol. Manag. 2018, 19, 75-87. [CrossRef]

3. Sellitto, M.A.; Luchese, J. Systemic Cooperative Actions among Competitors: The Case of a Furniture Cluster in Brazil. J. Ind. Compet. Trade 2018, 18, 513-528. [CrossRef]

4. Freixanet, J.; Renart, G.; Rialp-Criado, A. The Impact of Managers' Global Orientation on SME Export and Economic Performance. Manag. Int. Rev. 2018, 58, 571-604. [CrossRef]

5. Mejri, K.; MacVaugh, J.A.; Tsagdis, D. Knowledge configurations of small and medium-sized knowledge-intensive firms in a developing economy: A knowledge-based view of business-to-business internationalization. Ind. Mark. Manag. 2018, 71, 160-170. [CrossRef]

6. Miocevic, D.; Morgan, R.E. Operational capabilities and entrepreneurial opportunities in emerging market firms: Explaining exporting SME growth. Int. Mark. Rev. 2018, 35, 320-341. [CrossRef]

7. Carbone, J.C.; Rivers, N. The impacts of unilateral climate policy on competitiveness: Evidence from computable general equilibrium models. Rev. Environ. Econ. Policy 2017, 11, 24-42. [CrossRef]

8. Lan, J.; Chengjun, W.; Wei, Z. Investigation of the evaluation system of SMEs' industrial cluster management performance based on wireless network development. EURASIP J. Wirel. Commun. Netw. 2019. [CrossRef]

9. Sellitto, M.A.; Camfield, C.G.; Buzuku, S. Green innovation and competitive advantages in a furniture industrial cluster: A survey and structural model. Sustain. Prod. Consum. 2020, 23, 94-104. [CrossRef] 
10. Nara, E.O.B.; da Costa, M.B.; Baierle, I.C.; Schaefer, J.L.; Benitez, G.B.; do Santos, L.M.A.L.; Benitez, L.B. Expected Impact of Industry 4.0 Technologies on Sustainable Development: A study in the context of Brazil's Plastic Industry. Sustain. Prod. Consum. 2020. [CrossRef]

11. Castela, B.M.S.; Ferreira, F.A.F.; Ferreira, J.J.M.; Marques, C.S.E. Assessing the innovation capability of small- and medium-sized enterprises using a non-parametric and integrative approach. Manag. Decis. 2018. [CrossRef]

12. Laguir, I.; Den besten, M.D.; Elbaz, J.; Stekelorum, R. Sowing the seeds: The impact of initial ties on growth and innovation among micro and small firms. Econ. Bull. 2017, 37, 1021-1032.

13. Baregheh, A.; Rowley, J.; Sambrook, S. Towards a multidisciplinary definition of innovation. Manag. Decis. 2009, 47, 1323-1339. [CrossRef]

14. Fu, X.; Mohnen, P.; Zanello, G. Innovation and productivity in formal and informal firms in Ghana. Technol. Forecast. Soc. Chang. 2018, 131, 315-325. [CrossRef]

15. Borchardt, P.; dos Santos, G.V. Gestão de idéias para inovação: Transformando a criatividade em soluções práticas. Rev. Adm. Innov. 2014, 11, 203. [CrossRef]

16. Hervas-Oliver, J.L.; Sempere-Ripoll, F.; Boronat-Moll, C. Technological innovation typologies and open innovation in SMEs: Beyond internal and external sources of knowledge. Technol. Forecast. Soc. Chang. 2021, 162, 120338. [CrossRef]

17. Adams, P.; Bodas Freitas, I.M.; Fontana, R. Strategic orientation, innovation performance and the moderating influence of marketing management. J. Bus. Res. 2019, 97, 129-140. [CrossRef]

18. de Lima, D.D.; Lacerda, D.P.; Sellitto, M.A. Systemic Analysis of the Brazilian Production Chain of Semiconductors: Graphic Representation and Leverage Points. Syst. Pract. Action Res. 2017, 30, 295-316. [CrossRef]

19. Alonso, A.D.; Bressan, A. Micro and small business innovation in a traditional industry. Int. J. Innov. Sci. 2016, 8, 311-330. [CrossRef]

20. Quintane, E.; Mitch Casselman, R.; Sebastian Reiche, B.; Nylund, P.A. Innovation as a knowledge-based outcome. J. Knowl. Manag. 2011, 15, 928-947. [CrossRef]

21. Prokop, V.; Stejskal, J. Different approaches to managing innovation activities: An analysis of strong, moderate, and modest innovators. Eng. Econ. 2017, 28, 47-55. [CrossRef]

22. Agrawal, A.K.; Kumar, D.; Rahman, Z. An ISM approach for modelling the enablers of sustainability in market-oriented firms. Int. J. Bus. Excell. 2017, 12, 23-45. [CrossRef]

23. Yun, J.H.J.; Liu, Z. Micro- and macro-dynamics of open innovation with a Quadruple-Helix model. Sustainability 2019, 11, 3301. [CrossRef]

24. Li, T.; Ma, L.; Liu, Z.; Liang, K. Economic Granularity Interval in Decision Tree Algorithm Standardization from an Open Innovation Perspective: Towards a Platform for Sustainable Matching. J. Open Innov. Technol. Mark. Complex. Artic. 2020, 6, 149. [CrossRef]

25. Spezamiglio, B.d.S.; Galina, S.V.R.; Calia, R.C. Competitividade, inovação e sustentabilidade: Uma inter-relação por meio da sistematização da literatura. Rev. Eletrônica Adm. (Porto Alegre) 2016, 22, 363-393. [CrossRef]

26. D'Aleo, V.; Sergi, B.S. Does logistics influence economic growth? The European experience. Manag. Decis. 2017, 55, 1613-1628. [CrossRef]

27. Staniewski, M.W.; Awruk, K. Entrepreneurial success and achievement motivation-A preliminary report on a validation study of the questionnaire of entrepreneurial success. J. Bus. Res. 2019, 101, 433-440. [CrossRef]

28. Porter, M.E. Competitive strategy. Meas. Bus. Excell. 1997, 1, 12-17. [CrossRef]

29. Subramanian, N.; Gunasekaran, A.; Yu, J.; Cheng, J.; Ning, K. Customer satisfaction and competitiveness in the Chinese E-retailing: Structural equation modeling (SEM) approach to identify the role of quality factors. Expert Syst. Appl. 2014, 41, 69-80. [CrossRef]

30. Agrawal, A.; Catalini, C.; Goldfarb, A.; Luo, H. Slack Time and Innovation. Organ. Sci. 2018, 29, $1056-1073$. [CrossRef]

31. Moeuf, A.; Pellerin, R.; Lamouri, S.; Tamayo-Giraldo, S.; Barbaray, R. The industrial management of SMEs in the era of Industry 4.0. Int. J. Prod. Res. 2018, 56, 1118-1136. [CrossRef]

32. Arbussa, A.; Bikfalvi, A.; Marquès, P. Strategic agility-driven business model renewal: The case of an SME. Manag. Decis. 2017, 55, 271-293. [CrossRef] 
33. Park, K.J.; Yoo, Y. Improvement of competitiveness in small and medium-sized enterprises. J. Appl. Bus. Res. 2017, 33, 173-194. [CrossRef]

34. Majava, J.; Ojanperä, T. Lean Production Development in SMEs: A Case Study. Manag. Prod. Eng. Rev. 2017, 8, 41-48. [CrossRef]

35. Ulubeyli, S.; Kazaz, A.; Sahin, S. Survival of construction SMEs in macroeconomic crises: Innovation-based competitive strategies. J. Eng. Des. Technol. 2018, 16, 654-673. [CrossRef]

36. Barbosa Ferreira, J.A.; Coelho, A.; Weersma, L.A. The mediating effect of strategic orientation, innovation capabilities and managerial capabilities among exploration and exploitation, competitive advantage and firm's performance. Contad. Adm. 2019, 64. [CrossRef]

37. Dogru, T.; Mody, M.; Suess, C. Adding evidence to the debate: Quantifying Airbnb's disruptive impact on ten key hotel markets. Tour. Manag. 2019, 72, 27-38. [CrossRef]

38. Gómez-Vega, M.; Picazo-Tadeo, A.J. Ranking world tourist destinations with a composite indicator of competitiveness: To weigh or not to weigh? Tour. Manag. 2019, 72, 281-291. [CrossRef]

39. Li, Y.; Wang, L. Chaos in a duopoly model of technological innovation with bounded rationality based on constant conjectural variation. Chaos Solitons Fractals 2019, 120, 116-126. [CrossRef]

40. Martin-Rios, C.; Ciobanu, T. Hospitality innovation strategies: An analysis of success factors and challenges. Tour. Manag. 2019, 70, 218-229. [CrossRef]

41. Nora, L.D.D.; Siluk, J.C.M.; Júnior, A.L.N.; Soliman, M.; Nara, E.O.B.; Furtado, J.C. The performance measurement of innovation and competitiveness in the telecommunications services sector. Int. J. Bus. Excell. 2016, 9, 210-224. [CrossRef]

42. Oliveira, M.d.F.; Gomes da Silva, F.; Ferreira, S.; Teixeira, M.; Damásio, H.; Ferreira, A.D.; Gonçalves, J.M. Innovations in Sustainable Agriculture: Case Study of Lis Valley Irrigation District, Portugal. Sustainability 2019, 11, 331. [CrossRef]

43. Pucihar, A.; Lenart, G.; Kljajić Borštnar, M.; Vidmar, D.; Marolt, M. Drivers and Outcomes of Business Model Innovation-Micro, Small and Medium-Sized Enterprises Perspective. Sustainability 2019, 11, 344. [CrossRef]

44. Azar, G.; Ciabuschi, F. Organizational innovation, technological innovation, and export performance: The effects of innovation radicalness and extensiveness. Int. Bus. Rev. 2017, 26, 324-336. [CrossRef]

45. Saridakis, G.; Idris, B.; Hansen, J.M.; Dana, L.P. SMEs' internationalisation: When does innovation matter? J. Bus. Res. 2019, 96, 250-263. [CrossRef]

46. Assadinia, S.; Kadile, V.; Gölgeci, I.; Boso, N. The effects of learning orientation and marketing programme planning on export performance: Paradoxical moderating role of psychic distance. Int. Small Bus. J. Res. Entrep. 2019, 37, 423-449. [CrossRef]

47. Fuentelsaz, L.; Maicas, J.P.; Montero, J. Entrepreneurs and innovation: The contingent role of institutional factors. Int. Small Bus. J. Res. Entrep. 2018, 36, 686-711. [CrossRef]

48. Karami, M.; Tang, J. Entrepreneurial orientation and SME international performance: The mediating role of networking capability and experiential learning. Int. Small Bus. J. Res. Entrep. 2019, 37, 105-124. [CrossRef]

49. Exposito, A.; Sanchis-Llopis, J.A. Innovation and business performance for Spanish SMEs: New evidence from a multi-dimensional approach. Int. Small Bus. J. Res. Entrep. 2018, 36, 911-931. [CrossRef]

50. Maier, A.; Brad, S.; Dorin, M.; Nicoară, D.; Maier, D. Innovation by Developing Human Resources, Ensuring the Competitiveness and Success of the Organization Business processes performances improvement through integrated management of complex projects View project Redesign the security fences of robotic cells. Procedia Soc. Behav. Sci. 2014, 109, 645-648. [CrossRef]

51. Najafi-Tavani, S.; Najafi-Tavani, Z.; Naudé, P.; Oghazi, P.; Zeynaloo, E. How collaborative innovation networks affect new product performance: Product innovation capability, process innovation capability, and absorptive capacity. Ind. Mark. Manag. 2018, 73, 193-205. [CrossRef]

52. van de Vrande, V.; de Jong, J.P.J.; Vanhaverbeke, W.; de Rochemont, M. Open innovation in SMEs: Trends, motives and management challenges. Technovation 2009, 29, 423-437. [CrossRef]

53. Gunday, G.; Ulusoy, G.; Kilic, K.; Alpkan, L. Effects of innovation types on firm performance. Int. J. Prod. Econ. 2011, 133, 662-676. [CrossRef]

54. Isoherranen, V.; Ratnayake, R.M.C. Performance assessment of microenterprises operating in the Nordic Arctic region. J. Small Bus. Entrep. 2018, 30, 431-449. [CrossRef]

55. D'Souza, C.; Taghian, M. Small and medium size firm's marketing competitive advantage and environmental initiatives in the Middle East. J. Strateg. Mark. 2018, 26, 568-582. [CrossRef] 
56. OECD iLibrary. Proposed Guidelines for Collecting and Interpreting Technological Innovation Data: Oslo Manual; OCDE: Paris, France, 1997. Available online: https://www.oecd-ilibrary.org/science-and-technology/ proposed-guidelines-for-collecting-and-interpreting-technological-innovation-data_9789264192263-en (accessed on 15 October 2020).

57. Lee, C.; Hallak, R.; Sardeshmukh, S.R. Creativity and innovation in the restaurant sector: Supply-side processes and barriers to implementation. Tour. Manag. Perspect. 2019, 31, 54-62. [CrossRef]

58. Hjalager, A.M. A review of innovation research in tourism. Tour. Manag. 2010, 31, 1-12. [CrossRef]

59. Escola De Comércio, F.; Penteado, Á.; Biancolino, B.; Maccari, A.; Antonio, E.; Pereira, F. Innovation as a Tool for Generating Value in the IT Services Sector Revista Brasileira de Gestão de Negócios. Rev. Bras. Gestão Negócios 2013, 15, 410-426. [CrossRef]

60. Varis, M.; Littunen, H. Types of innovation, sources of information and performance in entrepreneurial SMEs. Eur. J. Innov. Manag. 2010, 13, 128-154. [CrossRef]

61. Guarascio, D.; Tamagni, F. Persistence of innovation and patterns of firm growth. Res. Policy 2019, 48, 1493-1512. [CrossRef]

62. Tavassoli, S.; Karlsson, C. Persistence of various types of innovation analyzed and explained. Res. Policy 2015, 44, 1887-1901. [CrossRef]

63. Zabeo, A.; Keisler, J.M.; Hristozov, D.; Marcomini, A.; Linkov, I. Value of information analysis for assessing risks and benefits of nanotechnology innovation. Environ. Sci. Eur. 2019, 31, 11. [CrossRef]

64. Acar, F.P. The effects of top management team composition on SME export performance: An upper echelons perspective. Cent. Eur. J. Oper. Res. 2016, 24, 833-852. [CrossRef]

65. Azam, A.; Boari, C.; Bertolotti, F. Top management team international experience and strategic decision-making. Multinatl. Bus. Rev. 2018, 26, 50-70. [CrossRef]

66. García-Cabrera, A.M.; García-Soto, M.G.; Durán-Herrera, J.J. Opportunity motivation and SME internationalisation in emerging countries: Evidence from entrepreneurs' perception of institutions. Int. Entrep. Manag. J. 2016, 12, 879-910. [CrossRef]

67. Gashi, P.; Hashi, I.; Pugh, G. Export behaviour of SMEs in transition countries. Small Bus. Econ. 2014, 42, 407-435. [CrossRef]

68. Aslesen, H.W.; Harirchi, G. The effect of local and global linkages on the innovativeness in ICT SMEs: Does location-specific context matter? Entrep. Reg. Dev. 2015, 27, 644-669. [CrossRef]

69. Monticelli, J.M.; Garrido, I.L.; de Vasconcellos, S.L. Coopetition and institutions: A strategy for Brazilian wineries facing internationalization. Int. J. Wine Bus. Res. 2018, 30, 74-95. [CrossRef]

70. Barkema, H.G.; Shvyrkov, O. Does top management team diversity promote or hamper foreign expansion? Strateg. Manag. J. 2007, 28, 663-680. [CrossRef]

71. Fernández-Serrano, J.; Romero, I. Entrepreneurial quality and regional development: Characterizing SME sectors in low income areas. Pap. Reg. Sci. 2012, 92. [CrossRef]

72. Oura, M.M.; Zilber, S.N.; Lopes, E.L. Innovation capacity, international experience and export performance of SMEs in Brazil. Int. Bus. Rev. 2016, 25, 921-932. [CrossRef]

73. Cuervo-Cazurra, A.; Genc, M. Transforming disadvantages into advantages: Developing-country MNEs in the least developed countries. J. Int. Bus. Stud. 2008, 39, 957-979. [CrossRef]

74. Guillén, M.F.; Garcia-Canal, E. The American model of the multinational firm and the "new" multinationals from emerging economies. Acad. Manag. Perspect. 2009, 23, 23-35. [CrossRef]

75. Adu-Gyamfi, N.; Korneliussen, T. Antecedents of export performance: The case of an emerging market. Int. J. Emerg. Mark. 2013, 8, 354-372. [CrossRef]

76. Tracey, P.; Phillips, N. Entrepreneurship in emerging markets strategies for new venture creation in uncertain institutional contexts. Manag. Int. Rev. 2011, 51, 23-39. [CrossRef]

77. Oliveira, G.A.; Tan, K.H.; Guedes, B.T. Lean and green approach: An evaluation tool for new product development focused on small and medium enterprises. Int. J. Prod. Econ. 2018, 205, 62-73. [CrossRef]

78. O'Dwyer, M.; Gilmore, A. Value and alliance capability and the formation of strategic alliances in SMEs: The impact of customer orientation and resource optimisation. J. Bus. Res. 2018, 87, 58-68. [CrossRef]

79. Hazarika, B.; Goswami, K. Micro-entrepreneurship Development in the Handloom Industry. Int. J. Rural Manag. 2018, 14, 22-38. [CrossRef]

80. Villa, A.; Taurino, T. From industrial districts to SME collaboration frames. Int. J. Prod. Res. 2018, 56, 974-982. [CrossRef] 
81. Dziallas, M.; Blind, K. Innovation indicators throughout the innovation process: An extensive literature analysis. Technovation 2019, 80-81, 3-29. [CrossRef]

82. Uyarra, E.; Edler, J.; Garcia-Estevez, J.; Georghiou, L.; Yeow, J. Barriers to innovation through public procurement: A supplier perspective. Technovation 2014, 34, 631-645. [CrossRef]

83. Schaefer, J.L.; Siluk, J.C.M.; Carvalho, P.S.d.; Renes Pinheiro, J.; Schneider, P.S. Management Challenges and Opportunities for Energy Cloud Development and Diffusion. Energies 2020, 13, 4048. [CrossRef]

84. Baierle, I.C.; Schaefer, J.L.; Sellitto, M.A.; Fava, L.P.; Furtado, J.C.; Nara, E.O.B. Moona software for survey classification and evaluation of criteria to support decision-making for properties portfolio. Int. J. Strateg. Prop. Manag. 2020, 24, 226-236. [CrossRef]

85. Tanskanen, K.; Ahola, T.; Aminoff, A.; Bragge, J.; Kaipia, R.; Kauppi, K. Towards evidence-based management of external resources: Developing design propositions and future research avenues through research synthesis. Res. Policy 2017, 46, 1087-1105. [CrossRef]

86. Pippel, G.; Seefeld, V. R\&D cooperation with scientific institutions: A difference-in-difference approach. Econ. Innov. New Technol. 2015, 25, 455-469. [CrossRef]

87. Capuano, C.; Grassi, I. Spillovers, product innovation and R\&D cooperation: A theoretical model. Econ. Innov. New Technol. 2019, 28, 197-216. [CrossRef]

88. Tsafarakis, S.; Gkorezis, P.; Nalmpantis, D.; Genitsaris, E.; Andronikidis, A.; Altsitsiadis, E. Investigating the preferences of individuals on public transport innovations using the Maximum Difference Scaling method. Eur. Transp. Res. Rev. 2019, 11, 3. [CrossRef]

89. Hon, A.H.Y.; Lui, S.S. Employee creativity and innovation in organizations: Review, integration, and future directions for hospitality research. Int. J. Contemp. Hosp. Manag. 2016, 28, 862-885. [CrossRef]

90. Luu, T.T. Can diversity climate shape service innovative behavior in Vietnamese and Brazilian tour companies? The role of work passion. Tour. Manag. 2019, 72, 326-339. [CrossRef]

91. Parjanen, S.; Hyypiä, M. Innotin game supporting collective creativity in innovation activities. J. Bus. Res. 2019, 96, 26-34. [CrossRef]

92. Lewandowska, M.S.; Szymura-Tyc, M.; Gołebiowski, T. Innovation complementarity, cooperation partners, and new product export: Evidence from Poland. J. Bus. Res. 2016, 69, 3673-3681. [CrossRef]

93. Bragge, J.; Kauppi, K.; Ahola, T.; Aminoff, A.; Kaipia, R.; Tanskanen, K. Unveiling the intellectual structure and evolution of external resource management research: Insights from a bibliometric study. J. Bus. Res. 2019, 97, 141-159. [CrossRef]

94. Nara, E.O.B.; Schaefer, J.L.; de Moraes, J.; Tedesco, L.P.C.; Furtado, J.C.; Baierle, I.C. Sourcing research papers on small- and medium-sized enterprises' competitiveness: An approach based on authors' networks. Rev. Esp. Doc. Cient. 2019, 42. [CrossRef]

95. Kowal, B. Key performance indicators in a multi-dimensional performance card in the energy sector. In IOP Conference Series: Earth and Environmental Science; Institute of Physics Publishing: Bristol, UK, 2019; Volume 214, p. 012093.

96. Nara, E.O.B.; Sordi, D.C.; Schaefer, J.L.; Schreiber, J.N.C.; Baierle, I.C.; Sellitto, M.A.; Furtado, J.C. Prioritization of OHS key performance indicators that affecting business competitiveness-A demonstration based on MAUT and Neural Networks. Saf. Sci. 2019, 118. [CrossRef]

97. Behrens, B.A.; Lau, P. Key performance indicators for sheet metal forming processes. Prod. Eng. 2008, 2, 73-78. [CrossRef]

98. Arca, J.M.; de Gutiérrez, V.E.; Castro, D.G. An approach to consequences of market orientation in the Basque social economy fostering public service|Aproximación a las consecuencias de la orientación al mercado en el servicio público de fomento de la economía social vasca. CIRIEC Espana Rev. Econ. Publica Soc. Coop. 2017, 89, 81-105. [CrossRef]

99. Sheehan, K.B. E-mail Survey Response Rates: A Review. J. Comput. Commun. 2006, 6. [CrossRef]

100. Baruch, Y.; Holtom, B.C. Survey response rate levels and trends in organizational research. Hum. Relat. 2008, 61, 1139-1160. [CrossRef]

101. Krause, D.; Luzzini, D.; Lawson, B. Building the Case for A Single Key Informant in Supply Chain Management Survey Research. J. Supply Chain Manag. 2018, 54, 42-50. [CrossRef]

102. Nara, E.O.B.; Gelain, C.; Moraes, J.A.R.; Benitez, L.B.; Schaefer, J.L.; Baierle, I.C. Analysis of the sustainability reports from multinationals tobacco companies in southern Brazil. J. Clean. Prod. 2019, 232. [CrossRef] 
103. Flynn, B.; Pagell, M.; Fugate, B. Editorial: Survey Research Design in Supply Chain Management: The Need for Evolution in Our Expectations. J. Supply Chain Manag. 2018, 54, 1-15. [CrossRef]

104. Kull, T.J.; Kotlar, J.; Spring, M. Small and Medium Enterprise Research in Supply Chain Management: The Case for Single-Respondent Research Designs. J. Supply Chain Manag. 2018, 54, 23-34. [CrossRef]

105. Treiblmaier, H.; Filzmoser, P. Exploratory factor analysis revisited: How robust methods support the detection of hidden multivariate data structures in IS research. Inf. Manag. 2010, 47, 197-207. [CrossRef]

106. Hair, J.; Anderson, R.; Babin, B.; Black, W. Multivariate Data Analysis: A Global Perspective (Vol. 7); Pearson Education: London, UK, 2010.

107. Da Costa, M.B.; Dos Santos, L.M.A.L.; Schaefer, J.L.; Baierle, I.C.; Nara, E.O.B. Industry 4.0 technologies basic network identification. Scientometrics 2019, 121. [CrossRef]

108. Frank, A.G.; Cortimiglia, M.N.; Ribeiro, J.L.D.; de Oliveira, L.S. The effect of innovation activities on innovation outputs in the Brazilian industry: Market-orientation vs. technology-acquisition strategies. Res. Policy 2016, 45, 577-592. [CrossRef]

109. Hrymak, V.; de Vries, J.M.A. The development and trial of systematic visual search: A visual inspection method designed to improve current workplace risk assessment practice. Policy Pract. Health Saf. 2020. [CrossRef]

110. Rajapathirana, R.P.J.; Hui, Y. Relationship between innovation capability, innovation type, and firm performance. J. Innov. Knowl. 2018, 3, 44-55. [CrossRef]

111. Lončar, D.; Paunković, J.; Jovanović, V.; Krstić, V. Environmental and social responsibility of companies cross EU countries-Panel data analysis. Sci. Total Environ. 2019, 657, 287-296. [CrossRef]

112. Krammer, S.M.S. Science, technology, and innovation for economic competitiveness: The role of smart specialization in less-developed countries. Technol. Forecast. Soc. Chang. 2017, 123, 95-107. [CrossRef]

113. Hojnik, J.; Ruzzier, M. Does it pay to be eco? The mediating role of competitive benefits and the effect of ISO14001. Eur. Manag. J. 2017, 35, 581-594. [CrossRef]

114. Sawhney, M.; Wolcott, R.C.; Arroniz, I. The 12 Different Ways for Companies to Innovate. IEEE Eng. Manag. Rev. 2006, 47, 75-81. [CrossRef]

115. Ketokivi, M.; Ali-Yrkkö, J. Unbundling R\&D and Manufacturing: Postindustrial Myth or Economic Reality? Rev. Policy Res. 2009, 26, 35-54. [CrossRef]

116. Gellynck, X.; Vermeire, B. The Contribution of Regional Networks to Innovation and Challenges for Regional Policy. Int. J. Urban Reg. Res. 2009, 33, 719-737. [CrossRef]

117. Nilsson, S.; Ritzén, S. Exploring the Use of Innovation Performance Measurement to Build Innovation Capability in a Medical Device Company. Creat. Innov. Manag. 2014, 23, 183-198. [CrossRef]

118. Yun, J.J.; Zhao, X.; Jung, K.; Yigitcanlar, T. The Culture for Open Innovation Dynamics. Sustainability 2020, 12, 5076. [CrossRef]

119. Bindabel, W. M\&A Open Innovation, and Its Obstacle: A Case Study on GCC Region. J. Open Innov. Technol. Mark. Complex. 2020, 6, 138. [CrossRef]

Publisher's Note: MDPI stays neutral with regard to jurisdictional claims in published maps and institutional affiliations.

(C) 2020 by the authors. Licensee MDPI, Basel, Switzerland. This article is an open access article distributed under the terms and conditions of the Creative Commons Attribution (CC BY) license (http://creativecommons.org/licenses/by/4.0/). 